\title{
FAKTOR-FAKTOR YANG BERHUBUNGAN DENGAN RENDAHNYA PENGGUNAAN KONTRASEPSI INTRA UTERINE DEVICE DI PUSKESMAS WAJOK HULU
}

\author{
Alexander ${ }^{1}$, Kamil Rusda Yani \\ Akademi Kebidanan Panca Bhakti Pontianak \\ Email korespondensi: akbidpbpontianak@gmail.com
}

\begin{abstract}
Abstrak
Di Kalimantan Barat, pasangan usia subur paling banyak menggunakan Non Metode Kontrasepsi Jangka Panjang (Non- MKJP) untuk mengatur jarak kelahiran, yaitu sebesar $87,9 \%$ sedangkan untuk MKJP adalah sisanya yaitu sebesar $12,1 \%$. Ada banyak faktor yang mempengaruhi rendahnya pemakaian alat kontrasepsi IUD. Tujuan penelitian ini adalah untuk mengetahui faktor-faktor yang berhubungan dengan pemilihan alat kontrasepsi di Puskesmas Wajok Hulu. Metode penelitian ini Cross Sectional analitik korelasi. Total sampel dalam penelitian ini adalah sebanyak 50 responden yang tidak menggunakan kontrasepsi Intra Uterine Devices di Puskesmas Wajok. Pengumpulan data menggunakan kuesioner kemudian diolah dan dianalisis menggunakan analisis univariat serta analisis bivariat menggunakan uji chi square. Hasil penelitian menunjukan bahwa 43 orang (86\%) berusia 20-35 tahun, 23 orang (46\%) berpendidikan rendah, 26 orang (52\%) berpengetahuan kurang, 34 orang (68\%) memiliki 1-4 anak, 26 orang (52\%) pendapatan tidak mempengaruhi dalam pemilihan alat kontrasepsi, 35 orang $(70 \%)$ agama tidak mempengaruhi dalam pemilihan alat kontrasepsi, 40 orang (80\%) dukungan suami mempengaruhi dalam pemilihan alat kontrasepsi, 35 orang $(70 \%)$ petugas kesehatan tidak mempengaruhi dalam memilih alat kontrasepsi, pemilihan alat kontrasepsi $16(32 \%)$ orang memilih PIL, 34 (68\%) orang memilih KB suntik. Berdasarkan hasil penelitian dapat disimpulkan bahwa ada hubungan antara faktor pengetahuan dan paritas. Puskesmas Wajok hulu dapat memberikan pendidikan penyuluhan konseling terhadap responden dalam pemilihan jenis kontrasepsi dan dapat menyediakan tempat konseling khusus.
\end{abstract}

Kata Kunci: Faktor, Kontrasepsi. IUD

\begin{abstract}
In West Kalimantan, most couples of childbearing age used Non-Long-Term Contraceptive Methods to regulate birth spacing, which is $87.9 \%$ while for Long Term Contraceptive Methods is $12.1 \%$. There are many factors that occurance the low use of IUD contraceptives. The purpose of this study was to determine the factors associated with the selection of contraceptives at the Wajok Hulu Health Center. The research method is Cross Sectional analytic correlation. The total sample in this study was 50 respondents who did not use Intra Uterine Devices contraception at the Wajok Health Center. Bivariate analysis using chi square test. The results showed that only 2 factors of 8 variables in this research had relationship, that is knowledge and parity. Data showed that $\mathrm{p}$ value $<0,05$, it means there is any relationship between knowledge and parity variable with low usage of IUD. And the other result showed that age, education, income, husband support and health worker had no relationship with low usage of IUD with $\mathrm{p}$ value $>0.05$. The Wajok Upstream Health Center can provide counseling counseling education to respondents in choosing the type of contraception and can provide a special counseling place.
\end{abstract}

Keyword: Factor, Contraception, IUD

\section{Pendahuluan}

Alat Kontrasepsi Dalam Rahim

(AKDR) adalah alat kontrasepsi yang

dimasukan kedalam rahim yang bentuknya

bermacam-macam, terdiri dari plastik

(polyethylene). Ada yang dililit tembaga $(\mathrm{Cu})$, ada pula yang tidak, ada pula yang dililit tembaga bercampur perak (Ag). Selain itu ada pula yang dibatangnya berisi hormon progesteron (Arum, 2009).

\footnotetext{
${ }^{1}$ Dosen Akademi Kebidanan Panca Bhakti Pontianak

${ }^{2}$ Mahasiswa Akademi Kebidanan Panca Bhakti Pontianak
} 
Di Kalimantan Barat, pasangan usia subur paling banyak menggunakan Non Metode Kontrasepsi Jangka Panjang (Non- MKJP) untuk mengatur jarak kelahiran, yaitu sebesar 87,9\% sedangkan untuk MKJP adalah sisanya yaitu sebesar 12,1\%. Untuk Non MKJP, penggunaan suntik sebagai alat untuk menunda kehamilan paling banyak dipilih oleh Pasangan Usia Subur (PUS) yaitu sebanyak 44,83\%, kemudian diikuti oleh penggunaan pil sebanyak 34,78\%. Sedangkan MKJP, penggunaan Implan merupakan alat kontrasepsi yang paling rendah diminati oleh PUS untuk menunda kehamilannya yaitu masing-masing sebesar $8,05 \%$ diikuti oleh penggunaan IUD sebesar 6,99\%. Sedangkan MOP dan MOW merupakan alat kontrasepsi Metode Kontrasepsi Jangka Panjang yang paling tidak diminati oleh PUS dalam menunda kehamilannya, yaitu masingmasing sebesar 2,03\% untuk MOP dan 0,74\% untuk MOW. Di Kabupaten Mempawah, peserta $\mathrm{KB}$ aktif paling banyak menggunakan kontrasepsi suntik (41,9\%) diikuti secara berturut-turut pil (38,8\%), IUD (5,18\%), Implan $(5,17 \%)$, kondom $(4,24 \%)$, MOW (2,7\%), MOP $(1,99 \%)$. Urutan ini juga sama persis untuk peserta KB baru dengan metode kontrasepsi terbanyak juga menggunakan metode suntik namun dengan jumlah persentase yang sedikit berbeda (Profil Dinas Kesehatan Kabupaten Mempawah Tahun 2015).

Salah satu masalah utama yang di hadapi saat ini adalah masih rendahnya penggunaan KB IUD. Sedangkan kecenderungan penggunaan $\mathrm{KB}$ lainnya meningkat. Angka penggunaan IUD yang masih rendah dapat disebabkan oleh berbagai faktor. Menurut Suparyanto, (2012) dalam artikelnya menyebutkan ada beberapa faktor yang rendahnya penggunaan metode kontrasepsi IUD ini, antara lain faktor internal yaitu pengalaman, takut, pengetahuan atau pengalaman yang salah tentang IUD, pendidikan Pasangan Usia Subur (PUS) yang rendah, malu dan risih, adanya penyakit persepsi tentang IUD. Faktor eksternal yaitu prosedur pemasangan IUD yang rumit, pengaruh dan pengalaman akseptor IUD lainnya, sosial budaya dan ekonomi pekerjaan.

Terkait dengan penggunaan kontrasepsi IUD, penting untuk mengetahui faktor-faktor yang mempengaruhi perilaku seseorang dalam pemakaian salah satu alat kontrasepsi. diantaranya faktor dari usia, pendidikan, pengetahuan, jumlah anak, pendapatan, agama, dukungan suami,dan pelayanan kesehatan.

Berdasarkan data dari Puskesmas Wajok metode kontrasepsi yang sangat diminati oleh masyarakat yaitu metode kontrasepsi suntik sebanyak, sedangkan pada MKJP IUD merupakan kontrasepsi yang kurang diminati masyarakat. Berdasarkan data yang diperoleh dimana penggunan kontrasepsi IUD masih rendah tentu ada faktor-faktor penyebabnya sehingga peneliti tertarik untuk melakukan penelitian mengenai faktor-faktor apa saja yang berhubungan dengan rendahnya penggunaan alat kontrasepsi IUD di Puskesmas Wajok Hulu Kabupaten Mempawah.

\section{Metode}

Pada penelitian ini menggunakan metode deskriptif korelasi dengan pendekatan secara cross sectional. Sampel dalam penelitian ini 
sebanyak $42 \mathrm{ibu}$ hamil yang melakukan pemeriksaan Antenatal Care di Puskesmas Wajok Hulu. Pengumpulan data menggunakan kuesioner, kemudian diolah dan dianalisis menggunakan analisis univariat serta analisis bivariat menggunakan uji chi square.

\section{Hasil dan Pembahasan}

Tabel 1. Faktor-Faktor Yang Berhubungan Dengan Rendahnya Penggunaan Kontrasepsi Intra Uterine Device Di Puskesmas Wajok Hulu

\begin{tabular}{|c|c|c|c|c|c|c|}
\hline \multirow{3}{*}{ Karakteristik } & \multicolumn{4}{|c|}{ Pemilihan Alat Kontrasepsi } & \multirow[b]{3}{*}{$\alpha$} & \multirow{3}{*}{ P Value } \\
\hline & \multicolumn{2}{|c|}{ Suntik } & \multicolumn{2}{|c|}{ Pil } & & \\
\hline & $\mathrm{N}$ & $\%$ & $\mathrm{~N}$ & $\%$ & & \\
\hline \multicolumn{7}{|l|}{ Usia } \\
\hline$<20$ tahun dan & 6 & 12 & 1 & 2 & & \multirow{3}{*}{0.323} \\
\hline$>35$ tahun & 6 & 12 & 1 & 2 & & \\
\hline 20-35 tahun & 27 & 54 & 16 & 32 & & \\
\hline \multicolumn{7}{|l|}{ Pendidikan } \\
\hline Rendah & 16 & 32 & 7 & 14 & & \multirow{3}{*}{0.378} \\
\hline Menengah & 14 & 28 & 6 & 12 & & \\
\hline Perguruan Tinggi & 3 & 6 & 4 & 8 & & \\
\hline \multicolumn{7}{|l|}{ Pengetahuan } \\
\hline Kurang & 18 & 36 & 8 & 16 & & \multirow{2}{*}{0.045} \\
\hline Cukup & 15 & 30 & 9 & 18 & & \\
\hline \multicolumn{7}{|l|}{ Paritas } \\
\hline Anak 1 dan > 4 anak & 14 & 28 & 2 & 4 & \multirow{3}{*}{0.05} & \multirow{2}{*}{0.028} \\
\hline Anak 2-4 anak & 19 & 38 & 15 & 30 & & \\
\hline \multicolumn{6}{|l|}{ Pendapatan } & \\
\hline Mempengaruhi & 17 & 34 & 9 & 18 & & \multirow{3}{*}{1.000} \\
\hline Tidak Mempengaruhi & 16 & 32 & 8 & 16 & & \\
\hline \multicolumn{6}{|l|}{ Agama } & \\
\hline Mempengaruhi & 9 & 18 & 6 & 12 & & \multirow{3}{*}{0.794} \\
\hline Tidak Mempengaruhi & 24 & 48 & 11 & 22 & & \\
\hline \multicolumn{6}{|l|}{ Dukungan suami } & \\
\hline Mempengaruhi & 28 & 56 & 12 & 24 & & \multirow{3}{*}{0.412} \\
\hline Tidak Mempengaruhi & 5 & 10 & 5 & 10 & & \\
\hline \multicolumn{6}{|l|}{ Petugas Kesehatan } & \\
\hline Mempengaruhi & 12 & 24 & 3 & 6 & & \multirow{2}{*}{0.297} \\
\hline Tidak Mempengaruhi & 21 & 42 & 14 & 28 & & \\
\hline
\end{tabular}

Faktor Usia dengan Rendahnya Penggunaan

Kontrasepsi Intra Uterine Device

Berdasarkan hasil uji statistik diperoleh nilai $\mathrm{P}=0.395 \quad(\mathrm{P}>0,05)$ maka dapat disimpulkan bahwa tidak ada hubungan usia dengan rendahnya penggunaan IUD.

Usia seseorang mempengaruhi jenis kontrasepsi yang dipilih. Demikian juga pendapat Sarwono (2011), mengatakan bahwa kontrasepsi pada PUS yang usia 20 tahun dianjurkan untuk menunda kehamilan, pada usia 20-30 tahun dianjurkan untuk membatasi jumlah anak yang diinginkan dengan fase berakhirnya kesuburan. Disarankan untuk tidak melahirkan dibawah umur 20 tahun dan setelah umur 35 tahun. Karena pada usia yang kurang 
dari 20 tahun dan setelah umur 35 tahun resiko komplikasi kehamilan dan melahirkan lebih tinggi.

Hal tersebut sejalan dengan penelitian yang dilakukan oleh Dewi Fatimah tentang faktorfaktor yang berhubungan dengan penggunaan alat kontrasepsi dalam rahim (AKDR) di Wilayah Kerja Puskesmas Kecamatan Pasar Rebo Jakarta timur tahun 2013 bahwa proporsi usia responden pemakaian alat kontrasepsi adalah usia >30 tahun $(83,6 \%)$ lebih banyak menggunakan alat kontrasepsi.

Penelitian ini tidak sesuai dengan teori yang mengatakan bahwa umur merupakan hal yang sangat dipertimbangkan dalam menentukan kehamilan dan mempertimbangkan penggunaan alat kontrasepsi (KBBI, 2011). Hal ini dilihat dari umur sebagian besar dari responden berumur 20-30 tahun dan lebih memilih kontrasepsi non MKJP.

Faktor Pendidikan dengan Rendahnya Penggunaan Kontrasepsi Intra Uterine Device

Hasil dari analisi bivariat dengan uji statistik Chi-square didapatkan tidak ada hubungan antara tingkat pendidikan dalam rendahnya penggunaan IUD dengan P-value 0.295 $(\mathrm{P}>0,05)$.

Tingkat pendidikan merupakan salah satu faktor yang mempengaruhi keikusertaan seseorang dalam program KB. Semakin tinggi tingkat pendidikan seseorang diharapkan semakin tinggi pula pengetahuan dan kesadarannya akan program KB.

Hasil penelitian ini tidak sesuai teori yang mengatakan tingkat pendidikan seseorang akan mempengaruhi kehidupan sosialnya, sehingga akan membuka kesadaran untuk memilih kontrasepsi yang terbaik dan sesuai dengan keinginannya dengan mempertimbangkan segi kesehatan serta tidak merugikan dirinya. Semakin tinggi tingkat pendidikan seseorang akan semakin besar kesadaran untuk memilih kontrasepsi yang lebih efektif dan bersifat jangka panjang. Hal ini dilihat dari hasil penelitian bahwa sebagian dari responden 7 orang (14\%) yang berpendidikan tinggi lebih memilih kontrasepsi non MKJP.

Penelitian ini sejalan dengan penelitian dilakukan oleh Fiona (2006), yang menyatakan bahwa tidak ada hubungan antara tingkat pendidikan dengan keikutsertaan perempuan dalam program KB. Hal ini tersebut disebabkan karena perempuan yang mempunyai tingkat pendidikan yang lebih tinggi belum tentu memiliki kesadaran yang tinggi tentang kesehatannya dan mandiri untuk datang ke pelayanan kesehatan.

Faktor Pengetahuan dengan Rendahnya Penggunaan Kontrasepsi Intra Uterine Device

Berdasarkan hasil uji statistik diperoleh nilai $\mathrm{P}$-value $=0.033 \quad(\mathrm{P}<0,05)$ maka dapat disimpulkan bahwa ada hubungan antara tingkat pengetahuan akseptor dengan rendahnya penggunaan IUD. Hal ini disebabkan karena rata-rata pengetahuan masyarakat di wajok hulu berpengetahuan kurang, semakin bagus tingkat pengetahuan seseorang maka akan semakin mempengaruhi dalam pemilihan alat kontrasepsi yang lebih efektif.

Pengetahuan seseorang terhadap objek mempunyai intensitas atau tingkat yang berbeda-beda. Tingkat pengetahuan yang cukup 
tentang kontrasepsi merupakan dasar bagi pasangan suami istri sehingga diharapkan semakin banyak yang memilih metode IUD (Nomleni dkk, 2014).

Hasil penelitian ini tidak sejalan dengan penelitian Dewi Fatimah (2013) yang menyatakan tidak ada hubungan antara pengetahuan dengan penggunaan alat kontrasepsi. Dari hasil penelitian didapatkan bahwa terdapat hubungan antara pengetahuan dengan rendahnya penggunaan alat kontrasepsi IUD. Hal ini dapat dilihat dari hasil penelitian diperoleh bahwa 7 orang $(12,7 \%)$ perempuan yang tidak menggunakan AKDR mempunyai pengetahuan kurang, 25 orang $(45,4 \%)$ perempuan yang tidak menggunakan AKDR mempunyai pengetahuan cukup baik, dan 23 orang $(41,8 \%)$ perempuan yang tidak menggunakan AKDR mempunyai pengetahuan baik.

Penelitian ini sesuai dengan teori pengetahuan adalah hasil penginderaan manusia, atau hasil tahu seseorang terhadap objek melalui indera yang dimilikinya (mata, hidung, telinga dan sebagainya). Dengan sendirinya, pada waktu penginderaan sampai menghasilkan pengetahuan tersebut sangat di pengaruhi oleh intensitas perhatian dan persepsi terhadap objek (Nomleni dkk, 2014).

Faktor Paritas dengan Rendahnya Penggunaan Kontrasepsi Intra Uterine Device

Berdasarkan analisis bivariat dengan uji statistik Chi-square didapatkan nilai P-value $0.043(\mathrm{P}<0,05)$ yang artinya ada hubungan antara paritas dengan rendahnya penggunaan IUD. Menurut Subiyatun dkk (2009), jumlah anak mempengaruhi pemilihan kontrasepsi yang akan digunakan. Semakin banyak anak yang dimiliki maka akan semakin besar kecenderungan untuk menghentikan kesuburan sehingga lebih cenderung untuk memilih metode kontrasepsi jangka panjang.

Penelitian sejalan dengan penelitian oleh Sindhy Desitavani (2017) yang menyatakan bahwa tidak ada hubungan antara paritas dengan pemilihan alat kontrasepsi IUD di kecamatan Bantul Yogyakarta, dengan nilai significancy pada hasil menunjukan $(\mathrm{P}=0,058$ $>0,05)$. Penelitian ini tidak sesuai teori yang menyatakan Ibu yang telah memiliki 2 anak atau lebih cenderung berminat menggunakan MKJP karena ibu mulai berfikir untuk berhenti memiliki anak terlebih lagi jika ibu telah berada pada usia tidak produktif karena ibu mulai memikirkan resiko persalinan (BKKBN, 2010). Hal ini dilihat dari jumlah rata-rata responden memiliki anak 2-4 orang tetapi lebih memilih kontrasepsi selain IUD.

Faktor Pendapatan dengan Rendahnya Penggunaan Kontrasepsi Intra Uterine Device

Berdasarkan analisis bivariat diperoleh nilai $\mathrm{P}$-value $=0,913 \quad(\mathrm{P}>0,05)$ maka dapat disimpulkan bahwa tidak ada hubungan antara pendapatan akseptor dengan rendahnya penggunaan IUD yang berarti tidak ada hubungan antara pendapatan dengan pemilihan alat kontrasepsi.

Tingkat ekonomi mempengaruhi pemilihan jenis kontrasepsi. Hal ini disebabkan karena untuk mendapatkan pelayanan kontrasepsi yang diperlukan akseptor harus menyediakan dana yang diperlukan. 
Hasil penelitian ini tidak sejalan penelitian Eminur Itri Sari (2016) yang mengatakan bahwa pendapatan berhubungan dengan minat MKJP (IUD). Pendapatan suatu keluarga berhubungan erat dengan kebutuhan-kebutuhan keluarga. Penghasilan seseorang merupakan salah satu faktor yang mempengaruhi penerimaan dan pengambilan keputusan terhadap inovasi baru. Hasil penelitian menunjukan bahwa responden menggunakan kontrasepsi hormonal lebih banyak yang berpendapatan keluarga rendah, sedangkan responden yang menggunakan kontrasepsi non hormonal lebih banyak yang berpendapatan tinggi. Hal ini menunjukan bahwa keinginan pasutri untuk menjadi akseptor KB masih tinggi meskipun pendapatan mereka tergolong rendah karena dilihat dari segi biaya, kontrasepsi hormonal yang digunakan cenderung lebih murah dibanding dengan kontrasepsi non hormonal.

Penelitian ini tidak sesuai dengan teori yang mengatakan bahwa tingkat ekonomi mempengaruhi pemilihan jenis kontrasepsi. Hal ini disebabkan karena untuk mendapatkan pelayanan kontrasepsi yang diperlukan akseptor harus menyediakan dana yang diperlukan. Hal ini dilihat dari hasil penelitian, bahwa terdapat 26 responden mengatakan bahwa pendapatan tidak mempengaruhi dalam pemilihan alat kontrasepsi.

\section{Faktor Agama dengan Rendahnya Penggunaan Kontrasepsi Intra Uterine Device}

Berdasarkan hasil uji statistik diperoleh nilai $\mathrm{P}$-value $=1,000 \quad(\mathrm{P}>0,05)$ maka dapat disimpulkan bahwa tidak ada hubungan antara agama akseptor dengan rendahnya penggunaan IUD. Hal ini mungkin disebabkan bahwa masyarakat menganggap semua jenis kontrasepsi itu sama dan menurut pandangan agama tidak dilarang.

Pandangan dari agama-agama tertentu ada yang melarang atau mengharamkan penggunaan IUD. Ada beberapa orang yang menganggap bahwa metode KB IUD termasuk yang dilarang dalam ajaran agama, karena beberapa produk IUD saat ini terbuat dari bahan yang tidak kondusif bagi zygote sehingga bisa membunuhnya dan proses kehamilan tidak terjadi (Mar'atul, 2010).

Hasil penelitian ini tidak sejalan dengan penelitian yang dilakukan oleh Lantan Rado (2015) yang meneliti "Gambaran Faktor-Faktor Yang Mempengaruhi Akseptor Tidak Memilih Kontrasepsi IUD di Puskesmas Sungai Raya Dalam Kabupaten Kuburaya tahun 2015”. Hasil penelitian menyimpulkan faktor-faktor yang mempengaruhi akseptor $\mathrm{KB}$ tidak memilih kontrasepsi IUD di Puskesmas Sungai Raya Dalam Kabupaten Kuburaya tahun 2015 yang paling dominan adalah faktor Agama, yaitu hampir seluruh responden yang menganut agama Islam yaitu 29 orang (97\%).

Penelitian ini tidak sesuai dengan teori bahwa pandangan dari agama-agama tertentu yang melarang atau mengharamkan penggunaan IUD. Ada beberapa orang yang menganggap bahwa metode KB IUD termasuk yang dilarang dalam ajaran agama, karena beberapa produk IUD saat ini terbuat dari bahan yang tidak kondusif bagi zygote sehingga bisa membunuhnya dan proses kehamilan tidak terjadi (Mar'atul, 2010). 
Faktor Dukungan Suami dengan Rendahnya Penggunaan Kontrasepsi Intra Uterine Device

Pada hasil penelitian ini diperoleh bahwa perempuan yang mendapat dukungan suami tidak mempengaruhi dalam pemilihan AKDR. Hasil analisis bivariat dengan uji statistik $C h i-$ square didapatkan tidak ada hubungan antara dukungan suami dengan rendahnya penggunaan IUD dengan $\mathrm{P}$-value $=0.820(p>0,05)$.

Pienem (2009) mengatakan bahwa terdapat dorongan bagi ibu untuk menggunakan AKDR, dalam hal ini merupakan faktor partisipasi suami. Program KB dapat terwujud dengan baik apabila terdapat dukungan dari pihak-pihak tertentu. Ikatan suami istri yang kuat sangat membutuhkan dukungan dari pasangannya. Dukungan tersebut akan tercipta apabila hubungan interpersonal keduanya baik.

Hasil penelitian ini tidak sejalan dengan penelitian oleh Dewi Fatima (2013) bahwa perempuan mendapatkan dukungan suaminya untuk menggunakan AKDR lebih banyak dibandingkan dengan perempuan yang tidak didukung oleh suaminya untuk mengggunakan AKDR. Hasil uji statistik diperoleh nilai $P$ value $=0,000 \quad(\mathrm{P}<0,005)$ maka dapat disimpulkan bahwa ada hubungan yang bermakna antara dukungan suami dengan penggunaan AKDR.

Hasil penelitian ini tidak sesuai dengan teori yang mengatakan bahwa terdapat dorongan bagi ibu untuk menggunakan AKDR, dalam hal ini merupakan faktor partisipasi suami. Program KB dapat terwujud dengan baik apabila terdapat dukungan dari pihak-pihak tertentu. Ikatan suami istri yang kuat sangat membutuhkan dukungan dari pasangannya. Dukungan tersebut akan tercipta apabila hubungan interpersonal keduanya baik. Hal ini dapat dilihat dari hasil penelitian sebagian besar dari responden yang mengatakan dukungan dari suami mempengaruhi, tetapi responden lebih banyak menggunakan kontrasepsi selain IUD.

\section{Faktor Petugas Kesehatan dengan}

\section{Rendahnya Penggunaan Kontrasepsi Intra}

\section{Uterine Device}

Berdasarkan hasil uji statistik diperoleh nilai $\mathrm{P}$-value $=0,390 \quad(\mathrm{P}>0,05)$ maka dapat disimpulkan bahwa tidak ada hubungan antara petugas kesehatan dengan rendahnya penggunaan IUD.

Pienem (2009) mengatakan, bahwa petugas kesehatan (pelayanan KB) dapat mempengaruhi seseorang dalam menggunakan AKDR. Sampai saat ini pelayanan $\mathrm{KB}$ yang diberikan oleh petugas kesehatan seperti komunikasi informasi dan edukasi masih kurang berkualitas. Terbukti dari peserta $\mathrm{KB}$ yang berhenti menggunakan alat kontrasepsi dengan alasan efek samping, kesehatan dan kegagalan pemakaian. Dengan memberikan pelayanan yang berkualitas khususnya informasi tentang KB AKDR, maka dapat mempengaruhi seseorang untuk menggunakan $\mathrm{KB}$ tersebut.

Hasil penelitian ini sejalan dengan penelitian Fiona (2006), yang menyatakan bahwa tidak ada hubungan bermakna anatara petugas kesehatan dengan keikutsertaan perempuan dalam berprogram KB. Hal ini disebabkan karena responden memang sudah memiliki pengetahuan dan kesadaran yang cukup baik sebelumnya, sehingga keikutsertaan dalam mengikuti penyuluhan atau pelayanan 
KB lainnya tidak mempengaruhi keikutsertaan perempuan dalam program KB.

Hasil penelitian ini tidak sejalan dengan teori yang menyatakan bahwa, bahwa petugas kesehatan (pelayanan KB) dapat mempengaruhi seseorang dalam menggunakan AKDR. Hal ini disebabkan karena di Puskesmas Wajok telah memfasilitasi pelayanan $\mathrm{KB}$, namun masyarakat masih tidak mau untuk menggunakan KB IUD.

\section{Kesimpulan}

Terdapat hubungan antara tingkat pengetahuan akseptor dengan rendahnya penggunaan IUD dan ada hubungan antara paritas dengan rendahnya penggunaan IUD di Puskesmas Wajok.

\section{Daftar Pustaka}

Arum. 2009. Panduan Lengkap Pelayanan KB Terkini. Mitra Cendika : Jogjakarta.

Arikunto, 2010. Prosedur Penelitian Suatu Pendekatan Praktik. Rineka Cipta : Jakarta

BKKBN. 2010. Alat Kontrasepsi KB Dan Keluarga Sejahtera. BKKBN : Jakarta.

Erna. 2015. Pelayanan Keluarga Berencana dan Kesehatan Reproduksi. Trans Info Media : Jakarta.

Fatimah. 2013. Faktor-Faktor Yang Berhubungan Dengan Penggunaan Alat Kontrasepsi Dalam Rahim (AKDR) Di Wilayah Kerja Puskesmas Kecamatan Pasar Rebo Jakarta Timur. http://repository.uinjkt.ac.id/dspace/bitstre am/123456789/25847/1/DEWI\%20FATI MAH-fkik.pdf,
Handayani, S. 2014. Buku Ajar Pelayanan Keluarga Berencana. Pustaka Rihama. Yogyakarta

Imbarwati. 2009. Beberapa Faktor Yang Berkaitan Dengan Penggunaan Kbiud Pada Peserta Kb Non Iuddi Kecamatan Pedurungankota Semarang. https://www.scribd.com/document/46170 292/Faktor-Faktor-Yang-MempengaruhiRendahnya-Akseptor-IUD-Di-Desa-KTIKEBIDANAN,

Irianto, K. 2014. Pelayanan Keluarga Berencana. Alfabeta : Bandung.

James. (2001). High Risk Pregnancy. Jakarta: EGC.

JIDAN. 2014. Faktor-faktorYang Berhubungan Dengan Penggunaan Alat Kontrasepsi Dalam Rahim Di Puskesmas Tatelu Kabupaten Minahasa Utara. https://media.neliti.com/media/publication s/91085-ID-faktor-faktor-yangberhubungan-dengan-pe.pdf,

Machfoedz. 2010. Metodelogi Enelitian Kuantitatif \& Kualitatif Bidang Kesehatan, Keperawatan, Kebidanan, Kedokteran. Fitramaya : Yogyakarta.

Manuaba. 2012. Ilmu Kebidanan, Penyakit Kandungan, Dan KB Untuk Pendidikan Bidan. EGC : Jakarta.

Notoatmoodjo, 2010. Metodelogi Penelitian Kesehatan. PT Rineka Cipta : Jakarta.

Pinem Sarohe, 2009. Kesehatan Reproduksi \& Kontrasepsi, TM : jakarta

Rawati, S Dkk. 2010. Panduan Memilih Kontrasepsi. Nuha Medika : Yogyakarta.

Sugiyono. 2011. Metode Penelitian Pendidikan. Alfabeta : Bandung.

Sujarweni. 2014. Metodelogi Penelitian Keperawatan. Gava Media : Yogyakarta . 
Suratun Dkk. 2008. Pelayanan Keluarga Berencana \& Pelayanan. Trans Info Media : Jakarta Timur.

Susila.2014. Metodelogi Penelitian Cross Sectional Kedokteran \& Kesehatan. Bossscript : Klaten.

Uliyah, M. 2010. Keluarga Berencana dan Alat KB. PT Bintang Pustaka Abadi : Yogyakarta.

Varney Helen, dkk.2006. Buku Ajar Asuhan Kebidanan. Jakarta : EGC. 